\title{
The Role of Offender Reintegration on Recidivism in Kakamega County, Kenya
}

\author{
Dr. Evans M. Oruta (Ph D) \\ Lecturer, Department of Criminology and Social Work \\ Masinde Muliro University of Science and Technology, Kenya, \\ Email: eoruta@mmust.ac.ke
}

\begin{abstract}
The International Centre for Prison Studies estimates that as of August 2016, over 11 million people were held in prison custody throughout the world. In spite of interventions by corrections to enable offenders to live crimefree lives after a period of incarceration, ex-convicts been exposed to the criminal justice system through either being re-arrested, re-convicted or re-incarcerated again and again, suggesting that the treatments and support systems they receive in and out of prison are either ineffective or non-existent. Since the founding of jails, people have faced challenges in transitioning from incarceration in penal facilities to liberty in the streets. The act of offenders encountering the criminal justice system after their release, whether through technical violations or new offences finds expression in the concept of recidivism. This study sought to investigate the role of offender reintegration on recidivism in Kakamega County, Kenya. The study adopted a survey research design in which 384 recidivists were sampled to take part in the study as respondents. Besides the recidivist, 25 Prison Officers, 13 Probation Officers, 27 family members of recidivists, and 18 community members from the neighbourhoods of recidivists bringing the target sample to 467 respondents. Out of the 467 targeted respondents, 412 participate in the study by way of adequately responding to items in the data collection instruments. This gives the study a response rate of 88.22 percent. Both probabilistic and non-probabilistic sampling techniques were used in sample selection. Data from respondents was collected using a questionnaire that was tested for validity and reliability prior to the actual data collection. Factor analysis was used to ascertain validity while Cronbach's Alpha coefficient of reliability was used to ascertain reliability of the questionnaire. Findings revealed a significant relationship between offender reintegration and recidivism among released prisoners in Kakamega County, Kenya $(\mathrm{r}=0.541 ; \mathrm{P}<0.01)$. The coefficient of determination $\left(\mathrm{R}^{2}\right)$ was 0.682 meaning that post-release treatment, ability to secure a job after release, access and use of certificate of good conduct, residence after release, vocational training while in prison and interaction with hard-core criminals while in prison account for $68.2 \%$ of variation in recidivism among released prisoners in Kakamega County, Kenya. In light of the study findings, it is recommended that the government and the various correctional stakeholders should come up with an integrated approach that specifically targets successful reentry of offenders upon release from prison.
\end{abstract}

Keywords: Offender Reintegration, Recidivism

DOI: $10.7176 / \mathrm{DCS} / 12-2-04$

Publication date: February $28^{\text {th }} 2022$

\subsection{Introduction}

Recidivism is an act of replication of an immoral act after that person has been harshly disciplined for that action or has been treated or trained to prevent that behaviour. Nevertheless, as with many other constructs in the social sciences, recidivism poses definitional challenges. The reason is that the conceptual definition is simple, but the operational definition is complex. What is included in the concept of recidivism has a significant impact on the level of recidivism recorded (CRS Survey, 2007: 9). This is due to the fact that the concept can be measured using data on re-arrest, re-incarceration, re-incarceration or technical infringement / revocation. As a consequence, calculating the frequency of recidivism is affected by how recidivism is calculated. In fact, recidivism can be assessed at various points of contact between a convicted perpetrator and the criminal justice system (Lievore, 2004: 41). Several criminologists claim that any further interaction with the criminal justice system no matter how mild the situation may be should be deemed recidivism on the part of an ex-offender.

According to Maltz (2001: 1), recidivism can be defined as the "reversion of an individual to criminal behaviour after he or she has been convicted of a prior offence, sentenced and allegedly corrected." Thus, recidivism is a relapse into criminal behaviour after being released from custody. A study conducted by Minnesota Comprehensive Offender Reentry Plan (2010: 33) measured recidivism in relation to re-arrest, reincarceration and re-incarceration of a new offense or re-incarceration following a technical violation or revocation of conditional release.

These definitions of recidivism are broad because they include technical violations of parole or probation, such as failure of a drug test or failure to appear for a meeting in the general statistics on recidivism (Maltz, 2001: 21). Technical violations are, therefore, in fact, an extension of the original prison term of the offender and not a 
new crime. The other shortcoming as a measure of recidivism is that the re-arrest statistics also include individuals who have been found innocent of the charges. As a legal principle, a suspect should not be found guilty unless he/she has been convicted by a court of competent jurisdiction. (MCORP, 2010: 39). Released prisoners in Kenya have a seventy-five percent risk of committing another crime and a fifty percent probability of going to jail two years following their release from prison. (Oruta, Omosa \& Lumumba, 2017:101), which compounds the high prison population problem and overcrowding. The high number of re-offenders was exacerbated by an increasing number of re-offenders being convicted for additional crimes. The extremely high rate of recidivism has immense costs in terms of public safety and money spent on investigating, punishing and incarcerating re-offenders. The Kenya National Bureau of Statistics Report (Republic of Kenya, 2017:272) indicates that in the year 2016, there were 14724 recidivists out of 57000 total prison population representing 25,8 percent. In the year 2017, there were 16371 male prisoners and 1453 female prisoners with a previous conviction record totaling 17826 recidivists in prisons (Kenya National Bureau of Statistics, 2018:267).

\subsection{Statement of the Problem}

The Kenya Prisons Service is mandated by the Prisons Act Chapter 90 Laws of Kenya, to handle rehabilitation and transformation of prisoners by learning, counseling education and career programmes. One of the core functions of the Kenya Prisons Service is rehabilitation and reformation of prisoners for social re-integration. The Probation Service in Kenya is charged with the reintegration and resettlement of offenders released from prisons through the aftercare services provided under the Probation of Offenders Act 11 of 2017.

Despite the resources spent by the State Department of Corrections, which comprises of the Kenya Prisons Service and the Probation Service to rehabilitate, reform and reintegrate offenders, a high rate of recidivism has been recorded in the country. According to the Kenya National Bureau of Statistics Report (Republic of Kenya, 2017: 272) in the year 2016, there were 14724 recidivists out of 57000 total prison population representing 25,8 percent. This cyclic movement of offenders to prisons from the community and back to prisons after release will without any doubt contribute enormously to the growth of the prison population and strain the allocated resources in addition to increased crime rates in the society, hence the need for this study.

\subsection{Research Objective}

To establish the role of offender reintegration on recidivism in Kakamega County

\subsection{Research Hypothesis}

$\mathbf{H}_{0}$ : Offender reintegration does not significantly influence recidivism in Kakamega County

\subsection{Study Justification}

The value of this study is outlined as follows:

This study is important as students and academics wishing to undertake studies on recidivism and its related concepts will use this study and its findings as a rich source of literature. The academia will further benefit in terms of stretched frontiers of knowledge in regard to the appropriate methodology employed, reviewed theoretical underpinnings of recidivism as well as the practical solutions to the challenges antecedent to recidivism in Kenya.

In addition, findings from this study will contribute to filling the knowledge gap with regard to recidivism. A review of the literature reveals limited information in the field of correlates studies regarding criminal recidivism among released offenders. In addition, the findings of this study will complement the existing knowledge base and understanding of recidivism in Kenya. The study suggests proper mechanisms based on an integrated prisoner management approach to prevent recidivism among released offenders.

Furthermore, the importance of this study is based on the study findings and recommendations that will provide a basis for policy formulation and application. This will influence approaches to resolving and managing the increased rates of recidivism in Kenya and globally. Specifically, correctional managers, the criminal justice system agencies, other government departments, and non-governmental organisations will use the findings of this research to inform their policies especially crime prevention strategies targeting recidivists. For instance, Kenya's Blueprint Vision 2030 identifies crime prevention as one of the key programmes which foster overall state-building, social development and social order.

\subsection{Literature Review}

Literature reviewed for the study is outlined in this section.

\subsubsection{Offender Reintegration and Recidivism}

Crime and its effects can be a defining moment for both perpetrators and suspects. Victims suffer both real and psychological damages as well as potential physical damage and social stigma correlated with being "victims." Offenders often flee into a vortex of toxic rationalisation that is exacerbated by obstacles encountered by ex- 
offenders, Van Ness and Karen (2015: 114). Reintegration sets a high priority of taking the necessary steps to support all those affected by crime and criminals re-enter their community as a whole, successful and active. Victims and criminals also share at least one common problem: each group is viewed as an outcast; each is stigmatised. Victims or criminals feel that they are intimidating many around them. Victims make non-victims feel more vulnerable "if it happens to her, it could happen to me." Offenders stir up anger and fear, "if he did it once, he will do it again" Van Ness and Karen (2015: 116).

The reintegration of the ex-inmates usually refers to re-entry and relocation. In this analysis, these terms are used interchangeably to describe strategies, programmes, and facilities designed to help inmates remain lawabiding in the society upon their release from prison. Reintegration includes the full spectrum of educational instruction and electronic monitoring, which is intended to reduce recidivism after the release of prisoners from custody. As such, the public and government priority are to facilitate the effective relocation of prisoners in the long term. Resettlement is a comprehensive, evidence-based mechanism through which steps are made to collaborate with the prisoner in prison and on release to ensure which populations are more resistant to injury and that reoffending is significantly reduced. It includes the entirety of efforts targeting inmates, their relatives and significant others in collaboration with state and non-governmental organisations. (Sampson \& Laub, 2001: 89).

Considering these predisposing factors of isolation, it is therefore essential for the evaluation of government measures to reduce recidivism. According to Laub (2007: 231), interventions aimed at preventing homelessness, poor education, deprivation, and other social problems can reduce crime. These and other primary and secondary crime prevention strategies, once introduced, can deter the occurrence or continuation of criminal behaviour.

Researchers in offender rehabilitation and re-entry believe that securing employment is a critical factor in offender reintegration. Lipsey (1999: 149) finds that getting employment is the single most effective means of reducing reoffending. Obtaining gainful employment is among the best predictors of the performance of prisoners upon release (Visher, Sara, Sherril \& Haner, 2005: 699). Studies have shown that high-quality jobs reduce the probability of reoffending. Research shows that ex-offenders who maintain steady jobs and close ties with their families are less likely to renew their offenses (Berg \& Huebner, 2011: 390).

Graffam, Shinkfield, Lavelle \& McPherson, (2004: 166) also argue that work offers more than the earnings needed to support sufficient material conditions. It also offers order and consistency when filling up space. This provides an opportunity to extend one's social network to include other productive members of society. Petersilia (2003: 21) states that finding a career upon release from prison is an important component of the inmate process because it enables ex-offenders to be active members of the community, to care for the families, to build work experience and to improve self-esteem, social networks and to live a conforming life.

Empirical research shows that providing ex-offenders with employment opportunities significantly lower their involvement in criminal behaviour (Duwe, 2012: 117; Mackenzie, 2006: 81; MCORP, 2010: 224; Sampson \& Laub, 2003: 19). Therefore, desistance is fundamentally based on work, in general seeking and maintaining a good job (Sampson \& Laub, 1993: 149; Bushway \& Reuter, 2002: 36).

Life-course theorists believe that employment and marriage constitute turning points in the lives of offenders and the pathway out of crime (Sampson \& Laub, 1993: 15). This is because work enables an offender to develop pro-social attitudes with conventional others (Warr, 1998: 200). Moreover, the informal social control mechanism at a workplace brings about a law-abiding life. Thus the role associated with employment reduces the possibility of offending because criminal behaviour is inconsistent with such status (Sampson \& Laub, 1993: 16). Analysing a longitudinal data on 500 men, Sampson \& Laub (2003: 71) found that during the periods of occupation, ex-offenders were less likely to commit a crime and engage in drug and alcohol abuse. This is because a steady job gives offenders a sense of identity and meaning to their lives and place restrictions on their routine activities, thereby decreasing their exposure to an environment conducive to criminal behaviour.

On the other hand, (Hagan \& McCarthy, 1997: 166; Sampson \& Laub, 1990: 92) also argue that the relationship is negative for adults. Thus life-course theorists suggest "age-graded correctional programmes reduce the social harm associated with recidivism" (Uggen, 2000: 537). From a life-course perspective, employment programmes are a crucial turning point in the criminal trajectories of older offenders. For instance, in their work on the age-graded theory of informal social control, Sampson and Laub (1990:611) found that it is "not employment per se" that reduces crime but rather the stability and commitment associated with employment. Writing on "Social Embeddedness of Crime and Unemployment", Hagan (1993: 233) suggests that juvenile delinquency prevents adolescents from accessing education and employment networks that help in adult employment. However, at age 26 when crime rates start to fall, the transitions to employment and marriage help in criminal desistance.

In order to ensure continuity of support for offenders, institutional programmes such as rehabilitation and reformation should be complemented with social and community support systems especially from the family and faith-based groups. Petersilia (2003: 71) has indicated that because of the challenges facing most offenders returning to the communities, providing re-entry services to support them would have favourable implications 
for them. This is because support services after release are intended to bond the former offender to conventional society, reducing unemployment and homelessness, prevent substance abuse, mental illness, and domestic violence. The re-entry services are seen as "what works" because it provides vocational training and employment, drug rehabilitation and halfway homes (Holliday et al, 2012: 1049).

Many of the criminological theories have established the importance of social support as a mechanism of criminal desistence. The social control theory postulates that a reduction in crime is a function of attachment to the family (Hirschi, 1969: 44). He finds that attachment to parents reduces the likelihood of antisocial behaviour. Social support reduces recidivism (Berg \& Huebner, 2011: 191; Visher \& Travis, 2003: 29) and act as a social control mechanism (Laub \& Sampson, 2003: 119). According to Berg and Huebner (2011: 39), social ties to family involve three social and psychological components that affect a reduction in criminal behaviour. Social ties have a controlling effect on returning offenders' behaviour, provide a provision of emotional support and facilitate identity transformation. In a study by Martin and Abrams (2013: 179), it was revealed that family provided for young offender returnees' expressive and instrumental support and at the same time through high expectations of the ex-offenders had the opportunity to restrict their movement to a non-offending identity. They describe this as "the ties that bind" (p.181).

Successful re-integration efforts should ensure that ex-offenders receive the necessary support by participating fully in social institutions. The implication is that ex-offenders must be provided with job skills, employment, and support from family and friends and neighbours such as social acceptance, love, care, counseling, and encouragement, financial and spiritual care. These serve to increase the bond to conventional society and reduce the likelihood of relapse into criminal activities. Through the theory of differential support and coercion, Colvin, Cullen and Vander Ven (2002: 203) explain that social support prevents crime but coercion is the main causal explanation of criminal behaviour. Social support can be more consistent or erratic with differential social-psychological effects. Consistent social support brings about trust and this sense of trust strengthens the social bonding leading to a commitment to others and social institutions. Thus support systems promote pro-social behaviour rather than self-interest and prevent crime.

Offender rehabilitation becomes effective correctional treatment when it is accompanied by post-release aftercare. The aftercare system is part of community supervision where aftercare officers who are social workers attached to a particular prison render essential services to the offenders. These services are so crucial in the reintegration of that offender into the communities. This is because, through the services, social workers assist in case management, post-release adjustment and the full resettlement of offenders after release. This post-release programme can reduce recidivism provided it is properly designed, well implemented and well selected. In analysis to assess the effects of a therapeutic community for substance abuse offenders accompanied by work release or aftercare, it was concluded that treatment intervention decreases re-arrest as a measure of recidivism (Inciardi, Martin, Butzin, Hooper, \& Harrison, 1997: 269). Wexler, Melnick, Lowe, and Peters, (1999: 324) find that participants of a three-year in-prison and community aftercare had a 27 percent re-incarceration rate, compared to 82 percent and 79 percent for offenders who did not take part in the programme and those in the control group respectively.

\subsubsection{Theoretical Underpinnings of Recidivism}

Recidivism is not explained by a single theory (Ryan \& Yang, 2005: 186). Correlations in relapsed offenders recidivism and criminal activity are the product of a complex phenomenon. Strain theories, labeling theory, differential social support and coercion theory and the social bond theory. These theories explain the relationship between socio-economic, human and environmental factors and recidivism.

\subsubsection{Strain theories}

In this category of strain theories, two theories are discussed, namely: the General Strain Theory by Robert Agnew and the Strain Theory by Robert K. Merton.

In 1992, Robert Agnew developed the General Strain Theory, partly as a response to the disadvantages and limitations of older strain models that were almost abandoned in the latter part of the 20th century (Agnew, Brezina, Wright, \& Cullen, 2002: 334; Slocum, Simpson, \& Smith, 2005: 468). Nevertheless, Agnew's strain model has origins that could probably trace back to the turn of the 19th century, when Emile Durkheim published his notorious novel, "Suicide" (Durkheim, 1897: 597). Durkheim's emphasis on self-destruction and suicide led him to the idea of anomie which he defined as a state of normality that could lead to a lack of norms or guidelines for people's behaviour (Durkheim, 1897: 693). As with Agnew's general theory of strain, Durkheim's concept of anomie is also quite direct, especially when looking at his explanation of anomie. Throughout his study of suicide, Durkheim speaks also about the influence of crises, and how crises reflect dislocations and irregularity throughout one's existing existence, forcing people into unusual or unknown circumstances (Durkheim, 1897: 699). Being in this state without rules or expectations as to what is appropriate or feasible can cause people to lose understanding and lead them to a state of dissatisfaction and torment triggered by their pursuit of unattainable goals and capabilities (Akers \& Sellers, 2004: 317).

The basic premise of the General Strain Theory by Robert Agnew is that strain causes frustration and other 
negative emotions which lead certain individuals to respond to criminal and delinquent coping strategies to such stressors or strains. Agnew believes that stress is crucial to understanding crime and describes crime and delinquency as the result of social-emotional strain, anger, and tension (Agnew, 2006: 189). Using General Strain Theory to explain the causes of recidivism, it suggests that engaging ex-offenders in illegal activity after release represents the coping mechanisms they pursue because of the stressors they face when released from prisons.

\subsubsection{The Labeling theory}

Labeling theory is founded on the premise that some members of society are capable of building and applying attributes to other members of the same society (Becker, 1963: 207). According to research, the application of a negative label by one social group to another produces another and thereby stigmatises the individual or group to which the tag has been applied and is considered beyond traditional society (Akers \& Sellers, 2009: 211; Becker, 1963: 201). Becker (1963: 201), the founder of labeling theory, stated that deviant behaviour only exists after members of society have defined it as such.

Labeling theory falls within the symbolic interactionist paradigm which assumes that one's identity and selfconcept are continuously determined by interactions with others and thus exist only on the basis of social interaction (Akers \& Sellers, 2009:169). This can, therefore, be concluded that those individuals who are negatively branded would incorporate this tag into their view of themselves. Goffman (1963: 73) assumed that those who were branded would not act in ways that undermined the tag, but rather display actions that validated it. Akers and Sellers (2009: 188) say a person will face humiliation and shame once it has been branded. It is these feelings that will provide motivation to engage in further deviant acts for labeled individuals. Furthermore, once labeled, the label recipients adopt the characteristics generated as part of their primary identity and live in ways that confirm the stereotypes attached to the label, thereby confirming their authenticity to the individual.

\subsubsection{The differential social support and coercion theory}

A modern systemic crime theory promoted by Colvin, Cullen and Vander Ven (2002: 37) is differential social support and coercion theory. It is based on two main topics, social support, and coercion. "Social support is an organized network of human relationships that help others meet their expressive and instrumental needs to prevent crime" (Colvin et al., 2002: 39). Social support can also be seen as supporting community members, social networks and trustworthy partners like wife or husband to fulfil the person's expressive and instrumental needs (Cullen, 1994: 547).

Expressive support includes feelings, self-worth, and integrity, while instrumental support includes physical and financial support, guidance and contacts in a legitimate society for positive social progress. It can be seen at different levels of society, such as family interactions, between mates, and within the broader social networks of peers, societies, and nations. Expressive and active social support networks are typically provided in informal social interactions between families and friends, as well as formal institutions such as universities, workplaces and health and criminal justice departments of government. The level of social support, however, differs across households, neighbourhoods, cultures, and nations. Social support reduces stress by providing the resources needed to help deal with the situation and prevent crime (Cullen \& Wright, 1999: 199). Social support strengthens social bonds because assistance ensures mutual trust between the donor and the recipient and thus prevents crime (Cullen, 1994: 545).

Therefore, coercion is the force that pressures or threatens an individual because of the dread it generates to obey specific instructions. Coercion can be interpersonal as it happens within the settings of the family or impersonal linking invisible forces like unemployment. Coercion may also involve the real or threatening elimination of social support (Colvin, 2000: 525). It is important to note that coercion leads to strain predisposing a person to commit a crime. Including social support, micro and macro-level coercion may occur. Patterson's micro-level manipulation (1990: 241) involves aversive interchanges between families and coercive disciplinary patterns. It also includes physical assaults and exchanges of non-physical coercion, including bullying, embarrassment, criticism, mistrust, and ostracism. Coercion yields alienated bonds while weak social bonds yield juvenile delinquency (Hirschi, 1969: 13). Agnew (2006: 43) states that the causes of stress are negative factors like being in an unwanted room or parental rejection. For example, coercive interpersonal relationships produce anger, and intensifying these relationships leads to authority defiance (Sherman, 1993: 450). In addition, unbiased demanding forces such as during a period of unemployment result in strain leading to crime.

\subsubsection{The Social bond theory}

Hirschi (1969: 39) suggested a model that explored the correlation among strong bonds and the probability of deviance in an attempt to explain criminal offences. This social bond hypothesis is constructed on the idea that all humans are susceptible to deviance and criminal activity, but can be regulated by the use of social bonds (Tibbetts \& Hemmens, 2015: 119). Such social bonds are characterised by connection, engagement, participation, and conviction held by "prosocial" people. Hirschi's Social Bond Theory notes that people who have strong ties to society are less likely to break the norms of society. Attachment refers to the emotional bond between 
individuals and their mates, families, and peers. Commitment is the amount of time and effort already invested in potential targets that may be wasted by criminal activity. Involvement is the time spent in non-crime activities. Finally, belief is the acceptance of conventional ideas and ideas. (Chriss, 2007: 46).

Tibbetts and Hemmens (2015: 12) note that attachment is the most critical social connection. Attachment is critical in imputing the norms of society and in cultivating a sense of self-control (Hirschi, 1969: 31). It can be argued that the other aspects of the social bond theory are solely dependent upon the attachment of the person.

Commitment is a reflection of what might be lost by deviating from social norms. Commitment will take the form of training, job skills and the exploration of numerous conventionally recognised avenues (Tibbetts \& Hemmens, 2015: 93). Hirschi (1969: 27) assumed that active participation in traditional practices would lead to less delinquency. Through completing certain tasks, the time of the adult cannot be spent in delinquency.

Belief is consistently linked with ethical beliefs in accordance with the law and culture. It refers to whether a person finds an activity unethical or not (Tibbetts \& Hemmens, 2015: 93). Hirschi (1969: 40) conducted a study to test his social bond theory. This test was performed on males involved in the Richmond Youth Prorgamme who were chosen from a random stratified sample. The sample consisted of 3605 adolescents and was structured to research the influence of attachment, commitment, participation, and belief. Hirschi drew his conclusions that attachment was primarily vital and that involvement had less impact (Kempf, 1993: 221).

\subsubsection{The Philosophy of Recidivism}

Recidivism is an act of replication of an immoral act after that person has been harshly disciplined for that action or has been treated or trained to prevent that behaviour. Nevertheless, as with many other constructs in the social sciences, recidivism poses definitional challenges. The reason is that the conceptual definition is simple, but the operational definition is complex. What is included in the concept of recidivism has a significant impact on the level of recidivism recorded (CRS Survey, 2007: 9). This is due to the fact that the concept can be measured using data on re-arrest, re-incarceration, re-incarceration or technical infringement / revocation. As a consequence, calculating the frequency of recidivism is affected by how recidivism is calculated. In fact, recidivism can be assessed at various points of contact between a convicted perpetrator and the criminal justice system (Lievore, 2004: 41). Several criminologists claim that any further interaction with the criminal justice system no matter how mild the situation may be should be deemed recidivism on the part of an ex-offender.

According to Maltz (2001: 1), recidivism can be defined as the "reversion of an individual to criminal behaviour after he or she has been convicted of a prior offence, sentenced and allegedly corrected." Thus, recidivism is a relapse into criminal behaviour after being released from custody. A study conducted by Minnesota Comprehensive Offender Reentry Plan (2010: 33) measured recidivism in relation to re-arrest, reincarceration and re-incarceration of a new offense or re-incarceration following a technical violation or revocation of conditional release.

These definitions of recidivism are broad because they include technical violations of parole or probation, such as failure of a drug test or failure to appear for a meeting in the general statistics on recidivism (Maltz, 2001: 21). Technical violations are, therefore, in fact, an extension of the original prison term of the offender and not a new crime. The other shortcoming as a measure of recidivism is that the re-arrest statistics also include individuals who have been found innocent of the charges. As a legal principle, a suspect should not be found guilty unless he/she has been convicted by a court of competent jurisdiction. (MCORP, 2010: 39).

Therefore, for the purposes of this review, recidivism should be more narrowly defined as a relapse of criminal behaviour contributing to re-arrest, re-conviction or re-incarceration. Focusing on re-incarceration with a new prison term is a more accurate measure of recidivism. This is because, unlike re-arrest, the re-arrest requires a plea from the defendant, reduces the likelihood of a wrong person being charged and reduces the means to ensure that the ex-offender has committed a new offense (Lievore, 2004: 53).

\subsection{Research Methodology}

The present study has been conducted by survey research design. This design is usually based upon samples whereby instead of directly studying whole populations, surveys typically collect evidence from a small sample of people selected from the population (Jupp, 2002:34). This design aids the researcher in collecting original data for the purposes of describing a population that is too large to observe directly. The study population comprises of recidivists serving custodial sentences in various Penal Institutions within Kakamega County, Western Region in Kenya, recidivists serving community sentences within the County, prison officers, probations officers, family members of recidivists, victims and their families, and local administrators in Kakamega County.

Both probabilistic and non-probabilistic sampling techniques are utilised in this study. Purposeful selection to classify members of the general population of prisoners based on the currently approved prison reports was used. This is because not all offenders in prisons qualify as respondents for this study, but only those who have been convicted more than once. Purposive sampling is also used to identify released prisoners who have successfully reintegrated into the community to participate as key informants.

Purposive sampling is used to identify key informants for the study including correctional service providers 
such as probation officers and prison officers. Local administrators, recidivists currently on community sentences, victims of recidivism, and family members of both the recidivists and victims are also purposively sampled. These are respondents who have been intentionally selected based on their peculiar characteristics, knowledge, feelings, and experiences in regard to correlates of recidivism among released prisoners. They understand the dynamics and transitional challenges faced by the prisoners upon release from prisons. Marlow (2005:87), reports that key informant sampling relies on people in the community identified as experts in the field of interest.

Stratified random sampling is used to achieve the desired representation proportionately from the various sub-groups in the recidivist population in prisons. The stratified sample consists of four groups based on the number of times each offender has been previously convicted. That is, those who have been convicted twice, thrice, four times and more than four times. After respondents are grouped into the respective strata, random sampling is finally used to identify the respondents with an appropriate number of subjects for each stratum being determined proportionately. Both primary and secondary sources of data are used in this study. Primary data sources are those observations collected at first hand through direct communication with the respondents for the specific purpose of addressing the criminological issues in question (Jupp, 2002:33). The primary data sources for this study include responses collected by the use of questionnaires, semi-structured interviews and focused group discussions from the field of study.

Secondary data sources include a review of the official statistics obtained from the Annual Kenya Economic Survey Reports, Kenya National Police Service, Kenya Prisons Service, Probation and Aftercare Service, resources from the media, textbooks, research findings, journal articles, magazines and internet databases. Most criminal justice research utilises data collected by Government agencies such as the Police, Criminal Courts, Probation and Corrections Services (Maxfield \& Babbie, 2015:230).

The study has both quantitative and qualitative data. Therefore, both descriptive and inferential statistics are used to analyse the data. Once the questionnaires were received they were coded and edited for completeness and consistency. After data from the questionnaires were edited, cleaned and coded, it was analysed. Kothari, (2004:131) indicates statistical measures that are used to analyse the survey data are

- Measures of central tendency such as the mean, median and mode are applied

- Measures of dispersion, that is, variance and standard deviation are commonly applied

- Measures skewness, mostly uses the first measure of skewness based on mean and mode or on mean and median

- Measures of relationship - amongst the measures of relationship, Karl Pearson's coefficient of correlation is the frequently used measure in case of statistics of variables, whereas Yule's coefficient of association is used in case of statistics of attributes. Multiple correlation coefficient, partial correlation coefficient, regression analysis

\subsection{Findings}

Study findings are presented in this section;

\subsubsection{Response rate}

The study targets 467 respondents comprising of

- 384 recidivists serving various prison terms in the three prisons within Kakamega County, namely Shikusa Main Prison, Kakamega Main Prison and Kakamega Women Prison;

- 25 Prison Officers;

- 13 Probation Officers;

- 27 family members of recidivists; and

- 18 community members from the neighbourhoods of recidivists.

Out of the 467 targeted respondents, 412 participate in the study by way of adequately responding to items in the data collection instruments. This gives the study a response rate of 88.22 percent. According to Sounders, Lewis and Thornhill (2009: 197), a response rate of over 80 percent is highly significant for purposes of generalisation of findings from a sample onto the entire population from which that particular sample is drawn.

\subsubsection{Relationship between offender reintegration and recidivism}

Both qualitative and quantitative analysis of the nexus between offender reintegration and recidivism are discussed in this section. The objective of the study sought to interrogate the relationship between offender reintegration and recidivism among released prisoners in Kakamega County. This is necessary to help the study to understand how rehabilitation programmes in prison, community reception of offenders upon release, postrelease social support structures and social interactions of offenders after release influence the likelihood of repeat offending. The following null hypotheses are formulated to guide the study;

\section{$\mathrm{H}_{0}$ : Offender reintegration does not have a significant influence on recidivism}

Study data relating to community reintegration and that relating to recidivism are subjected to various descriptive and inferential statistics. The Pearson Product Moment Correlation Coefficient is performed between offender 
reintegration and recidivism among released prisoners in Kakamega County and findings are presented in Table 1

Table 1: Relationship between offender reintegration and recidivism

\begin{tabular}{llll}
\hline & & Offender Reintegration & Recidivism \\
Reintegration & Pearson Correlation & 1 & \\
& Sig. (2-tailed) & \\
Recidivism & $\mathrm{N}$ & 329 & \\
& Pearson Correlation & $.541(* *)$ & 1 \\
& Sig. (2-tailed) & .000 & \\
& $\mathrm{~N}$ & 329 & \\
\hline
\end{tabular}

** Correlation is significant at the 0.01 level (2-tailed).

(Field data, 2018)

Study findings in Table 1 reveal a significant relationship between offender reintegration and recidivism among released prisoners in Kakamega County $(\mathrm{r}=0.541 ; \mathrm{P}<0.01)$. The implication of this finding is that rehabilitation programmes in prison, community reception of offenders upon release, post-release social support structures and social interactions of offenders after release, the possibility of securing a job after release and availability and access to support from faith-based organisations influence the likelihood of recidivism among released prisoners in Kakamega County.

Since the study revealed a statistically significant relationship between offender reintegration and recidivism at the level of significance of 0.01 , the null stating that offender reintegration does not have a significant influence on recidivism is hereby rejected and its alternative offender reintegration has a significant influence on recidivism adopted.

To determine the direction and magnitude of the influence of the various study constructs for offender reintegration as used in the study, the researcher has subjected the study data to multivariate regression analysis and findings presented in Table 2

Table 2: Multiple regression results for offender reintegration on recidivism

\begin{tabular}{lccc}
\hline Variable & Coefficients & t-value & p-value \\
\hline Constant & 0.263 & 2.890 & 0.005 \\
Post Release Treatment & 0.513 & 3.669 & $0.000^{*}$ \\
Job After release & & 1.724 & $0.0002^{*}$ \\
Certificate of Good Conduct & 0.935 & 4.629 & $0.000^{*}$ \\
Residence & 0.183 & 4.552 & $0.001^{*}$ \\
Vocational Training & 0.133 & 5.727 & $0.000^{*}$ \\
Interaction with hard Core Criminals & 0.381 & 0.421 & 5.871
\end{tabular}

Goodness of Fit:

R2 0.682

Adjusted R2 0.659

F-value 3.828

\section{(Filed data, 2018)}

Findings in Table 2 show multiple regression results for offender reintegration factors as predictors of recidivism among released prisoners in Kakamega County. The constructs investigated are post-release treatment, ability to secure a job after release, access and use of a certificate of good conduct, residence after release, vocational training while in prison and interaction with hard-core criminals while in prison. Study findings establish that calculated $t$-statistics $(t=3.669,1.724,4.629,4.552,5.727$ and 5.871) for the following parameters respectively are greater than tabulated t-statistics at 0.05 level of significance: post-release treatment, ability to secure a job after release, access and use of certificate of good conduct, residence after release, vocational 
training while in prison and interaction with hard-core criminals while in prison. The result of the study shows that all the six constructs have a significant influence on recidivism given that all the $\mathrm{p}$ values are less than 0.05 .

The coefficient of determination $\left(\mathrm{R}^{2}\right)$ is 0.682 meaning that post-release treatment, ability to secure a job after release, access and use of certificate of good conduct, residence after release, vocational training while in prison and interaction with hard-core criminals while in prison account for $68.2 \%$ of variation in recidivism among released prisoners in Kakamega County. The remaining 38.1 percent unknown parameter was largely due to variance outside of the regression model in other factors that are otherwise included in the stochastic error term. In spite of its overall fitness quality, the cumulative regression method is statistically significant $(\mathrm{f}=3.867$, $\mathrm{P}<0.05)$.

A descriptive analysis of study data relating to offender reintegration is presented in Table 3 .

Table 3: Frequency distribution for reintegration factors

\begin{tabular}{|c|c|c|c|}
\hline Variable & $\begin{array}{l}\text { Total } \\
(\mathrm{N}=329)\end{array}$ & $\begin{array}{l}\text { Male } \\
(\mathrm{N}=298)\end{array}$ & $\begin{array}{l}\text { Female } \\
(\mathrm{N}=31)\end{array}$ \\
\hline \multicolumn{4}{|l|}{ Participation in post release treatment } \\
\hline Yes & $79.2 \%$ & $53.5 \%$ & $25.7 \%$ \\
\hline No & $13.9 \%$ & $9.7 \%$ & $4.2 \%$ \\
\hline \multicolumn{4}{|l|}{ Secured a job after release from prison } \\
\hline Yes & $29.1 \%$ & $19.8 \%$ & $9.3 \%$ \\
\hline No & $63.7 \%$ & $48.5 \%$ & $15.2 \%$ \\
\hline \multicolumn{4}{|l|}{ How the job was secured after release } \\
\hline Through friends & $39.8 \%$ & $27.9 \%$ & $11.9 \%$ \\
\hline Through family members & $27.4 \%$ & $18.3 \%$ & $9.1 \%$ \\
\hline Through programmes assisting ex-offenders & $3.2 \%$ & $1.9 \%$ & $1.3 \%$ \\
\hline Through personal efforts & $18.9 \%$ & $13.1 \%$ & $5.8 \%$ \\
\hline \multicolumn{4}{|l|}{ Whether police clearance was necessary } \\
\hline Yes & $23.5 \%$ & $22.3 \%$ & $1.2 \%$ \\
\hline No & $69.3 \%$ & $57.1 \%$ & $12.2 \%$ \\
\hline \multicolumn{4}{|l|}{ Type of employment sought } \\
\hline Formal job in government & $17.4 \%$ & $13.5 \%$ & $3.9 \%$ \\
\hline Formal job in private sector & $63.7 \%$ & $49.1 \%$ & $14.6 \%$ \\
\hline Others & $9.1 \%$ & $7.7 \%$ & $1.4 \%$ \\
\hline
\end{tabular}

(Field data, 2018)

Note: Data presented are weighted by gender.

The sample size varies slightly for select variables due to missing values.

Study findings in Table 3 reveal that $79.2 \%$ of respondents reported receiving post-release treatment while $13.9 \%$ did not receive post-release treatment. It is also established that $63.7 \%$ of respondents did not secure a job immediately upon release from prison while $29.1 \%$ secured a job immediately upon release from prison. Concerning the assistance received in securing a job after release from prison, the modal response category is through friends at $39.8 \%$. A paltry of respondents $3.2 \%$ received jobs through programmes for assisting released offenders. This means that there is a significant scarcity of programmes to assist released offenders to address their employment needs upon release from prisons. The study revealed that $69.3 \%$ of respondents did not find certificates of good conduct necessary in securing jobs after release from prison, while $23.5 \%$ found them necessary in securing jobs after release from prison. In respect to the type of employment sought after release from prison, the modal response category was formal jobs in the private sector $63.7 \%$.

Further descriptive analysis of reintegration factors is conducted to gauge the ease of offender reintegration back to the community upon release from prison and findings presented in Table 4 
Table 4: Frequency distribution for reintegration factors

\begin{tabular}{|c|c|c|c|}
\hline Variable & $\begin{array}{l}\text { Total } \\
(\mathrm{N}=329)\end{array}$ & $\begin{array}{l}\text { Male } \\
(\mathrm{N}=298)\end{array}$ & $\begin{array}{l}\text { Female } \\
(\mathrm{N}=31)\end{array}$ \\
\hline \multicolumn{4}{|c|}{$\begin{array}{l}\text { Whether lack of good conduct certificate was a hindrance in } \\
\text { securing a job }\end{array}$} \\
\hline Strongly agree & 7.4 & $5.9 \%$ & $1.5 \%$ \\
\hline Agree & $11.4 \%$ & $8.3 \%$ & $3.1 \%$ \\
\hline Neutral & $29.8 \%$ & $21.7 \%$ & $8.1 \%$ \\
\hline Disagree & $21.9 \%$ & $15.1 \%$ & $6.8 \%$ \\
\hline Strongly Disagree & 19.5 & $12.8 \%$ & $6.7 \%$ \\
\hline \multicolumn{4}{|c|}{ Residence before imprisonment } \\
\hline Rural home & $34.1 \%$ & $23.7 \%$ & $10.4 \%$ \\
\hline Rented house in urban area & $27.9 \%$ & $19.1 \%$ & $8.8 \%$ \\
\hline Relative's home & $19.4 \%$ & $16.3 \%$ & $24.2 \%$ \\
\hline Friend's home & $13.9 \%$ & $8.2 \%$ & $5.7 \%$ \\
\hline \multicolumn{4}{|c|}{ Whether former residence was secured after release from prison } \\
\hline Yes & $71.4 \%$ & $56.8 \%$ & $14.6 \%$ \\
\hline No & $19.4 \%$ & $11.9 \%$ & $7.5 \%$ \\
\hline \multicolumn{4}{|c|}{ Treatment during the last incarceration } \\
\hline Yes & $31.3 \%$ & $22.4 \%$ & $8.9 \%$ \\
\hline No & $65.1 \%$ & $50.2 \%$ & $14.9 \%$ \\
\hline
\end{tabular}

(Field data, 2018)

Note: Data presented are weighted by gender.

The sample size varies slightly for select variables due to missing values.

Respondents were asked whether lack of a certificate of good conduct was a hindrance for them to secure a job after release from prison and findings in Table 4 reveal that the modal response category is neutral with $29.8 \%$ implying that most respondents are not sure that possession of a certificate of good conduct or lack of it is really necessary for securing a job. The study also establishes that most respondents resided in their rural homes before imprisonment, which represents $34.1 \%$ while $71.45 \%$ of respondents were able to secure their former residence after previous releases from prison. In addition, the study reveals that $65.1 \%$ of respondents did not receive any form of treatment during their last incarceration. This could explain why they relapsed after release from prison given the vital role of offender treatment as a strategy for behaviour change.

Respondents were requested to state the kind of treatment received in prison that would be a basis for their reintegration upon release and findings presented in Table 5

Table 5: Frequency distribution for reintegration factors

\begin{tabular}{|c|c|c|c|}
\hline Variable & $\begin{array}{l}\text { Total } \\
(\mathrm{N}=329)\end{array}$ & $\begin{array}{l}\text { Male } \\
(\mathrm{N}=298)\end{array}$ & $\begin{array}{l}\text { Female } \\
(\mathrm{N}=31)\end{array}$ \\
\hline \multicolumn{4}{|l|}{ Type of treatment received } \\
\hline Substance abuse treatment & 5.2 & $4.8 \%$ & $0.4 \%$ \\
\hline Sex offender treatment & $21.7 \%$ & $18.3 \%$ & $3.4 \%$ \\
\hline Anger management & $19.5 \%$ & $12.7 \%$ & $6.8 \%$ \\
\hline Formal education & $33.3 \%$ & $21.4 \%$ & $11.9 \%$ \\
\hline Vocational training & 17.9 & $9.1 \%$ & $8.8 \%$ \\
\hline \multicolumn{4}{|c|}{ Importance of treatment in prison } \\
\hline Strongly agree & $28.8 \%$ & $16.5 \%$ & $12.3 \%$ \\
\hline Agree & $23.5 \%$ & $14.9 \%$ & $8.6 \%$ \\
\hline Neutral & $16.9 \%$ & $10.1 \%$ & $6.8 \%$ \\
\hline Disagree & $19.5 \%$ & $13.9 \%$ & $5.6 \%$ \\
\hline Strongly Disagree & $6.7 \%$ & $4.9 \%$ & $1.8 \%$ \\
\hline \multicolumn{4}{|c|}{ Whether currently undertaking any treatment } \\
\hline Yes & $69.1 \%$ & $48.9 \%$ & $20.2 \%$ \\
\hline No & $28.3 \%$ & $19.5 \%$ & $8.8 \%$ \\
\hline
\end{tabular}

(Field data, 2018)

Note: Data presented are weighted by gender.

The sample size varies slightly for select variables due to missing values.

With regard to the type of treatment received while in prison, the study reveals a modal response category of formal education with $33.3 \%$. This points to the willingness of offenders to learn and change their ways given the opportunity. A significant number of offenders $(28.8 \%)$ strongly agree that offender treatment is important and $69.1 \%$ replied to the affirmative that they were currently undergoing some form of treatment. The high 
number of respondents who indicated that they did not receive any treatment during their last incarceration and an equally higher number who indicated that they are currently receiving treatment are pointers to the fact that there could be a shift in policy at the prisons department to engage in offender rehabilitation as a strategy for behaviour change aimed at reducing recidivism.

Respondents were asked whether they had contact with hard-core criminals while in prison and if the same would hinder effective reintegration and also whether there were any linkages facilitated by prisons for family and community members to interact with imprisoned offenders before release and findings presented in Table 6

Table 6: Frequency distribution for reintegration factors

\begin{tabular}{|c|c|c|c|}
\hline Variable & $\begin{array}{l}\text { Total } \\
(\mathrm{N}=329)\end{array}$ & $\begin{array}{l}\text { Male } \\
(\mathrm{N}=298)\end{array}$ & $\begin{array}{l}\text { Female } \\
(\mathrm{N}=31) \\
\end{array}$ \\
\hline \multicolumn{4}{|c|}{ Interaction with hardcore criminals } \\
\hline Yes & $71.9 \%$ & $5.9 \%$ & $1.5 \%$ \\
\hline No & $19.6 \%$ & $8.3 \%$ & $3.1 \%$ \\
\hline \multicolumn{4}{|c|}{ Whether such interaction increased chances of reoffending } \\
\hline Strongly agree & $37.1 \%$ & $26.3 \%$ & $10.8 \%$ \\
\hline Agree & $27.5 \%$ & $17.8 \%$ & $9.7 \%$ \\
\hline Neutral & $14.1 \%$ & $9.3 \%$ & $3.8 \%$ \\
\hline Disagree & $11.1 \%$ & $7.5 \%$ & $3.6 \%$ \\
\hline Strongly disagree & $8.9 \%$ & $6.4 \%$ & $2.5 \%$ \\
\hline \multicolumn{4}{|c|}{ Involvement in re-entry programmes } \\
\hline Yes & $13.5 \%$ & $8.9 \%$ & $4.6 \%$ \\
\hline No & $74.1 \%$ & $58.2 \%$ & $15.9 \%$ \\
\hline \multicolumn{4}{|c|}{$\begin{array}{l}\text { Necessity to conduct programmes involving convicts, } \\
\text { community and victims before release }\end{array}$} \\
\hline Strongly agree & $32.8 \%$ & $19.1 \%$ & $13.7 \%$ \\
\hline Agree & $30.9 \%$ & $22.8 \%$ & $8.1 \%$ \\
\hline Neutral & $13.1 \%$ & $9.3 \%$ & $3.8 \%$ \\
\hline Disagree & $11.9 \%$ & $8.7 \%$ & $3.2 \%$ \\
\hline Strongly Disagree & $9.8 \%$ & $6.4 \%$ & $\begin{array}{l}3.4 \% \\
\text { Field da }\end{array}$ \\
\hline
\end{tabular}

Note: Data presented are weighted by gender.

The sample size varies slightly for select variables due to missing values.

Study findings reveal that $71.9 \%$ of respondents interact with hard-core criminals while in prison and when asked if such interaction with hard-core criminals increased their chances of re-offending, the study achieved a modal response category of strongly agree $37.1 \%$. This shows that most respondents are aware that contact with hard-core criminals (mostly out of no choice) has a direct relationship with recidivism.

Respondents were asked whether they were involved in any re-entry programmes prior to their release from prison and $74.1 \%$ revealed that they were not involved in re-entry programmes. When asked to comment on the importance of re-entry programmes involving family, community members and victims of crime prior to release from prison, the modal response category was strongly agree $32.8 \%$. This shows that offenders appreciate the importance of re-entry programmes as a means to prepare for a safe and harmonious return home from prison. It needs not to be emphasized that such re-entry programmes foster reconciliation, reintegration, and restitution between offenders, the victims and the communities where they come from. Re-entry programmes also help the government to prepare environmental adjustment reports that ensure the security and safety of both the accused persons, the victims of crime and the community in the event that the accused persons are released from prison.

Interviewed Probation and Prison Officers were requested to provide information regarding the nexus between offender reintegration and repeat offending among released prisoners in Kakamega County, Kenya. Study findings from interviews with Probation Officers reveal that the majority of Probation Officers $(81.05 \%)$ were of the view that offenders who adhered to scheduled rehabilitation plans drawn for them by correctional officers were less likely to recidivate as compared to those who did not follow rehabilitation plans.

According to an interview by 7 Probation Officers based at Kakamega Central Sub-County and 5 Probation Officers based at Mumias Probation office, the following categories of offenders/offences qualify for community sentences

- Offenders who commit minor offences against persons and/or property such as simple stealing;

- Housebreaking; and

- Simple assault.

Such offences which are punishable to 3 years imprisonment or less can be committed to community sentences. The community sentences are Probation Orders and Community Service Orders. Probation Orders draw their legal mandate from the Probation of Offenders Act. A Probation Order is a sentence imposed by a 
Criminal Court to an offender to provide for the supervision of the offender in the community by a probation officer for purposes of offender reformation (Republic of Kenya, 2012: 5).

Whenever an offender is sentenced to a period on probation, a probation officer is required by law to compile a treatment plan that would help the offender to be rehabilitated so as to refrain from criminal activities. Probation Officers mostly use evidence-based treatment of offenders, including motivational interviewing and cognitive behavioural therapy to help offenders to rediscover their potential and shun criminality (Obondi, 2017: $68)$.

Offenders' rehabilitation under a sentence of probation sentence requires that an offender reports to a probation officer once a month or sooner, depending on the offender's needs and risk analysis. Offenders serving probation sentences are assessed for their risks and needs and appropriate empowerment interventions provided mainly to reduce their chances of recidivism. Offenders with skills in tailoring, carpentry, masonry, electric wiring and painting works are usually identified during motivational interviewing and are recommended for empowerment with tools and capital to start their own life afresh. This helps to reduce the chances of recidivism. Other offenders who do not have trade skills are trained on how to make detergents, shampoo and how to develop model tree nurseries. All this is intended to keep the offenders gainfully engaged to disabuse them of any thoughts of repeat offending.

According to the Community Service Orders Act number 10 of 1998, Community Service Order is a sentence imposed by a Criminal Court to an offender deemed non-injurious to the community (Republic of Kenya, 1998:3). Such offenders are those who would have been imprisoned for less than three years. Offenders sentenced to a community service order are required to abide by prescribed conditions and are subject to imprisonment should they violate the conditions of the order. Community Service Order Programme draws its mandate from the Community Service Orders Act. Offenders placed on Community Service Orders are required to offer unpaid public service work to the community. This is a form of retribution and giving back to the community which the offender wronged through his/her crime. Examples of public work done by offenders on community service include

- Digging of pit latrines in schools;

- Cleaning of market places schools, dispensaries, and other public places;

- Opening, and expanding up of rural access roads; and

- Clearing of bushes and unclogging of drainages.

During the Community Service Order's period, which in most cases is a maximum of three years, Probation Officers compile a rehabilitation plan for the offender. The objective of the rehabilitation plan is to ensure that the offender does not fall back into re-offending.

Additionally, Probation Officers organise reconciliation sessions between offenders in prison, their family members and the families of victims of crime before the release of the offender(s) back into the community upon completion of their incarceration terms. This helps to prepare the offender's re-entry into the community and also prepares their family members and the families of the victims of their crimes and the community at large for proper reconciliation with the offender upon release from prison.

The families of offenders are a potential source of support and assistance upon re-entry into the community. A common attribute of persons in conflict with the law is the absence of family support. The social control theory postulates that a reduction in crime is a function of attachment to the family (Hirschi, 1969: 44). He finds that attachment to parents reduces the likelihood of antisocial behaviour. Social support reduces recidivism (Berg \& Huebner, 2011: 191; Visher \& Travis, 2003: 29) and act as a social control mechanism (Laub \& Sampson, 2003: 119). According to Berg and Huebner (2011: 39), social ties to family involve three social and psychological components that affect a reduction in criminal behaviour.

Prison Officers were of the view that offenders who complete their training in skilled craft such as tailoring, carpentry, masonry, and painting while in prison were less likely to re-offend (Kimani, 2016:86),. According to responses from interviews with Prison Officers, there is an established Chaplaincy Section in every Prison. The chaplaincy office has been mandated with spiritual matters of prisoners and spearheading counseling sessions. This is in line with spiritual rehabilitation which is quite active in all prisons in Kakamega County. The chaplaincy office normally invites external religious organisations to provide spiritual empowerment to the inmates. Most inmates respond positively to such initiatives. It is less likely for the offenders who accepted salvation while in prison to engage in repeat offending. Prisons also allow families of inmates to visit their relatives in prison as a way to prepare both the family members and the inmate for the return of the inmate back home at the end of the prison sentence.

As a strategy to reduce the negative influence between hard-core criminals and petty offenders while in prison, Prison Officers admit different categories of offenders to different accommodation units. In this regard, hard-core criminals and petty offenders are separated. According to interviews with Prison Officers, there are three categories of offenders in prison and each category is incarcerated separately as follows

- Capital offenders - those offenders who committed offences punishable by death or life sentences such 
as murder, robbery with violence and treason;

- Inmates sentenced to very long sentences of over ten years in prison - sexual offenders, those convicted for causing grievous bodily harm, arson, possession of firearms and ammunition and attempted suicide; and

- Inmates convicted for petty offences - affray, assault, traffic offences, stealing, burglary, forest-related offences, and other misdemeanours.

However, Prison Officers based at Shikusa Prison, Kakamega Main Prison and Kakamega Women Prison noted that in some instances, like during meals, sporting activities, entertainment, etc, all prisoners can meet and interact freely. Such unavoidable interaction provides an opportunity for offenders to exchange negative values.

Focus group discussions with ex-offenders' family members, representatives of the victims' family, community members, local administration and religious leaders were conducted to determine whether offenders had been assisted by any agency, either governmental or non-governmental in the process of resettlement and reintegration. This was important given that reintegration involves the safe return of the offender back into the community and his/her peaceful co-existence with community members upon release from prison. Post-release interventions should support the immediate transition from the prison to the community so as to reinforce the gains achieved during prison treatment and continue until a successful reintegration is completed (Fox, 2002: 123).

Findings reveal that a large majority of the family $(67.5 \%)$ and community members $(59.1 \%)$ were of the view that most ex-offenders were not provided with tools and other necessary support to assist them in resettlement after release from prison. However, there were exceptional cases where a few ex-offenders had received support directly from the State Department of Correctional Services or from Non-Governmental organisations like Ahadi trust and Rodi Kenya.

This is what one ex-prisoner from Musoli area within Kakamega South Sub-County who had been sentenced to twenty years imprisonment at Kakamega G.K Prison had to say when asked if he received support upon release:
“.....I was sentenced to serve twenty years imprisonment for the offence of manslaughter. After fourteen years in prison, the Power of Mercy Advisory Committee requested for a report from Probation Officers......the officers interviewed me and recommended that I be released from prison since I was remorseful and circumstances at home had changed.... while in prison I had trained in carpentry up to grade one level and issued with a certificate of competence. Probation Officers recommended me for empowerment and linked me to Ahadi Trust who issued me with a free carpentry toolkit, rented for me a workshop at Musoli Market and paid six months' rent. They bought me timber worth fifteen thousand Kenya shillings and also bought me five hundred tokens of electricity for my new workshop..... I am now settled down and I will be able to educate my two children, marry another wife and never go back to crime again”. Musoli Sub- Location Office (24/6/2018)

Another respondent hail from Emutetemo Village in Mumias East Sub-County. She had been previously incarcerated for six months in prison for the offence of brewing illicit liquor and discharged upon expiry of the sentence. She was later re-arrested and charged in Court for the offence of selling illicit brew barely two months after her release from prisons and placed under six months Community Service Order. She had this to say when asked if she had been assisted by way of provision of tools or equipment to help her settle down upon release from prison:
“.... I was not given tools since I did not have any prior training or skills in any trade....only those people who stayed in prison for long and were trained in some trades were considered for empowerment by way of tools and equipment provision.......we were just called to the probation office during their open day and a person from an NGO called Rodi Kenya trained us on how to make liquid detergents and Shampoo.....we were not given any capital to start off but it is a very interesting skill..... if I get money I will try to make liquid detergents and supply to schools and dispensaries around my community to legitimately earn some money.....”. Emutetemo village (27/6/2018)

This indicates that some released offenders are fully supported, while others were partially empowered given their length of stay in prison, nature, and extent of skill level as well as the interest of the offender to further their trade. This means that those offenders who were sentenced to short prison terms did not undergo any significant rehabilitation programme, and also they do not receive support from stakeholders. This makes them be more likely to recidivate.

Close family and community members were asked whether offenders had sought or secured any gainful 
employment after release from prison. Responses had mixed reactions with some indicating that some exoffenders had sought gainful employment while others did, not alluding to the fact that some offenders had not secured gainful employment after release from prison. A focus group discussion with family members of an offender living in Shivagala Village of Shirere sub-location within Kakamega Central Sub-County who was recently released from Shikusa Prison after serving a six-month sentence had this to say when asked if the offender had sought or secured any employment:

"......he has no time to look for work.......he roams the village day and night and people suspects that he still engages in criminal activities.....he spends most of his time gambling, drinking alcohol, smoking bhang and seducing old women.......it will not be surprising to get information that he has been re-arrested again..... ". Shivagala village (28/6/2018).

A village elder of Shikoho village in Kakamega South sub-County had this to say when asked if his neighbour who had been imprisoned for twelve months at Shikusa Prison sought any gainful employment upon his release:

“....that boy has been working at a construction site at Shikoho Secondary School where he has been undertaking menial work on a Constituency Development Fund (CDF) funded project for the last three months. He is normally paid three hundred and fifty shillings everyday ......he reformed and we have never heard that he is involved in any bad company, he attends to church service every Sunday where he even testifies that he has changed from his criminal ways, .... the boy is truly reformed... "Shikoho village, (28/6/2018).

Empirical research shows that providing ex-offenders with employment opportunities significantly lower their involvement in criminal behaviour (Mackenzie, 2006: 81; Sampson \& Laub, 2003: 19). Thus desistance depends critically on employment, specifically finding and holding a good job (Bushway \& Reuter, 2002: 36). Obtaining legal employment is one of the best predictors of the post-release success of offenders (Visher, Sara, Sherril \& Haner, 2005: 699).

The Village elder noted that the boy underwent a rehabilitation programme while in prison which has helped him to resettle back into the community. This means that prison offender rehabilitation can have a significant role in reducing recidivism and it increases the chances of successful re-entry of offenders into the community upon release from prisons.

Focus group interviews also asked family members of recidivists to state whether their offending relatives had gained any skills while in prison and whether they were utilising the skills gained. Responses were mixed. Some family members stated that their offending relatives had not gained any skills while in prison given that they were sentenced to shorter sentences. Other family members indicated that their relatives who had been sentenced to serve long sentences due to the severity of the offences committed were trained in various skills. Some of the skills cited include; Painting, electrical wiring, masonry, carpentry, metalwork and farming. The majority of those who completed vocational training were applying their skills to earn a living safe for a few who for one reason or another did not have the necessary tools of trade.

One offender had served a two-year prison sentence for the offence of shop breaking and stealing. He had this to say when he was asked if he was utilising skills gained while in prison:
"I spent two years in prison and got trained in carpentry up to grade two. I was not empowered with any tools but I was promised that I will be considered by the probation officer since she had submitted my name to the Empowerment Committee. I am currently attached to an experienced carpenter at Lubao market where I have gained immense skills in carpentry. I am looking forward to opening my own workshop when I get equipment from Probation Officers. The supervising probation officer has visited me once at home and twice at the workshop to see my progress and seriousness. I believe I will receive my tools soon." Lubao Market (29/6/2018).

\subsection{Recommendations}

The study unveiled that offenders who successfully reintegrated into the community recorded low levels of recidivism. The government should, therefore, invest in the reintegration of offenders to prevent recidivism. The study recommends that the government and the various correctional stakeholders should come up with an integrated approach that specifically targets successful reentry of offenders upon release from prison. An interagency relationship and partnership should be formed that simultaneously addresses the multiple needs of ex-offenders upon release and deal with systematic challenges faced by ex-offenders upon release. A close working relationship should be formed and maintained among National Government and County Government 
administrators, law enforcement officers, correctional officers, treatment counselors, criminologists, social workers, medical professionals, non-governmental organisations and other professionals. These agencies and professionals should work constructively and enhance communication among themselves in order to facilitate the successful reintegration of offenders back into the community and avoid recidivism.

Reentry programmes play an important role in the successful reentry of offenders and desistance from criminal behaviour. Correctional officers should actively involve offenders, their families, victims and their families and the community at large in an effort to cooperatively achieve a just response to criminal harm. Emphasis should be laid on restorative justice programmes that prioritise restoring a sense of well-being to those harmed by criminal acts, the offender and the community at large. This can be achieved through mediations between the victims and the offenders, reparations, conferencing and negotiation.

Implementation of a comprehensive post-release treatment plan and after-care services for released offenders would greatly reduce levels of recidivism. Concerning this, correctional officers should utilise available assessment tools to establish individual offender's risk, need and responsivity factors and draw postrelease treatment plans that address the specific criminogenic needs of offenders. A number of assessment instruments incorporating dynamic risk factors and criminogenic needs of the offenders are available to correctional practitioners. Such an instrument is an "Offender Assistant System" which was rolled out in probation areas and prisons in England and Wales between 2001-2004 (Robinson \& Crow, 2009: 94). The instrument is designed to meet a comprehensive specification touching on the assessment of reconviction, incorporating both static and dynamic factors and a structured format for the assessment of the risk of harm. Criminogenic areas covered by the Offender Assistant System are accommodation, education, training, employability, financial management; relationships, lifestyle, and associations, drug use, emotional well-being, thinking, behaviour and attitude. The instrument allows the correctional officer to establish a link between an area under examination e.g. accommodation, financial management, etc. with the risk of re-offending. The results obtained will enable correctional officers to draw post-release treatment plans that are geared towards addressing offenders' specific criminogenic needs and challenges. Risk/needs assessment instruments can also provide a measure of the effectiveness of treatment plans that offenders are subjected to as well as provide a hint on the likelihood of relapse.

There is the existence of an opportunity to rehabilitate offenders who have been incarcerated to transform them into law-abiding citizens upon release from custody in order to reduce recidivism. Effective intervention programmes in prisons have a significant impact on enforcing the social functioning of offenders upon release and thus reducing recidivism. Prisons should enhance their rehabilitation programmes to adequately prepare offenders for a crime-free life and successful re-entry into the community upon release.

\section{List of references}

Bureau of Justice Statistics (2017). Prisoners in 2017. Washington, DC: Bureau of Justice Statistics.

Bureau of Justice Statistics (2018). Special Report on Prisoner Recidivism. Washington, DC: Bureau of Justice Statistics.

Bureau of Justice Statistics (2019). Special Report on Prisoner Recidivism. Washington, DC: Bureau of Justice Statistics.

Carney, L.P. (1977). Probation and parole: legal and social dimension. USA: McGraw Hill.

Carney, L.P. (1979). Introduction to correctional science. 2nd edition. USA: McGraw- Hill.

Carson, E.A., \& Sabol, W. J. (2012). Prisoners in 2011. Washington, DC: Bureau of Justice Statistics.

Champion, D.J. (2001). Corrections in the United States: A contemporary perspective. $3^{\text {rd }}$ edition. New Jersey: Upper Saddle River.

Chief Inspector of Prisons (2015) Annual Report 2014-15, London: HM Stationery Office.

Department of Correctional Services (1998). Correctional Services Act 1998111 of 1998. From $<$ www.dcs.org.za> (Retrieved on 25 June 2018).

Elizabeth, P., Barbara, O., \& Jason, C. (2007). Recidivism Among Female Prisoners: Secondary Analysis of the 1994 BJS Recidivism Data Set. Washington: US Department of Justice

Graunbol, H.M., Kiieltrup, B., Muilu, V.L., Tiny, S.I., Baldursson, E.S, Guomundsdottir, H., \& Lindsten, K. (2010). Return: A Nordic study of recidivism among clients in the criminal justice system.

Hanns von, H. (2011). Punishment and Crime in Scandinavia, 1750-2008. Crime and Justice 40:1 pages 284313.

Hudson, K., Maguire, Mike., Raynor, P. (2007). Through the Prison Gate: Resettlement, Offender Management and the Birth of the 'Seamless Sentence.

Ikponwosa, E., \& Richard S. (2012). Finnish Criminal Policy: From a Hard Time to Gentle Justice. Journal of Prisoners on Prisons, Vol. 21. No. 1 \& 2, 2012

Institute for Criminal Policy Research. (2019). World Prison Brief. https://www.prisonstudies.org/ Retrieved on $30^{\text {th }}$ July, 2019 
Jules-Macquet, R. (2014). The State of South African Prisons. NICRO Public Education Series, Edition 2. Cape Town: National Institute for Crime Prevention and the Reintegration of Offenders.

Lappi-Seppälä, T. (2012). Imprisonment and Penal Policy in Finland. Penal Policy in Scandinavia. Vol.- 36.

Martinson, R. (1974). 'What works? Questions and answers about prison reform', The Public Interest. 35: 22-54.

Ministry of Justice. (2016). Proven Reoffending Statistics: Definitions and Measurement London: Ministry of Justice

Ministry of Justice. (2017). Annual National Offender Management Service digest: 2016 to 2017, London: Ministry of Justice

Ministry of Justice. (2018) Annual HM Prison and Probation Service digest: 2017 to 2018, London: Ministry of Justice.

Ministry of Justice. (2018). Proven reoffending statistics: April 2016 to June 2016, London: Ministry of Justice

Ministry of Justice. (2019). Proven reoffending statistics: July to September 2017, London: Ministry of Justice

O'Connor, R. (2014). The United States prison system: A comparative analysis. Florida: University of Florida.

Osayi, K.K. (2013). 'Socio-cultural affecting reintegration of discharged prisoners in Anambra State, South East, and Nigeria'. Mediterranean Journal of Social Science, 4 (10):775-780.

Peter, L., \& Eric, L. (2016). The Swedish prison system. Stockholm: Ministry of Justice Reno, J., Marcus, D., Leary, M., \& Gist, N. (2000). Alleviating jail overcrowding, a systems perspective. Washington, DC: Bureau of Justice Statistics.

Republic of South Africa (1996). Constitution of the Republic of South Africa. Pretoria: Government Press.

Shanta, B. (2016). Offender Rehabilitation and Reintegration: A South African Perspective. Journal of Social Sciences. Vol. 46, 2016 -Issue 1.

Swedish Prison and Probation Service (2007). Prison Treatment Act. Norrköping: Government Press

Petersilia, J. (2003). When Prisoners Come Home: Parole and Prisoner Re-entry, New York: Oxford University Press.

Robinson, G \& Crow, I. (2009). Offender rehabilitation: Theory, research, and practice. : Los Angeles

Travis, J. (2005). But they all come back: Facing the challenges of prisoner reentry. Washington, DC: Urban Institute Press.

Uggen, C. \& Thompson, M. (2003). The socio-economic determinants of ill-gotten gains: Within- person changes in drug use and illegal earnings. American Journal of Sociology, Vol.109 (No.1), pp.146. 